\title{
Effect of Thermal and Alkaline Disintegration of Excess Sludge on Biodegradation
}

\author{
Iwona Zawieja' \\ ${ }^{1}$ Czestochowa University of Technology, Faculty of Infrastructure and Environment, Institute of Environmental \\ Engineering, Brzeznicka 60a, 42-200 Czestochowa, Poland \\ e-mail: izawieja@is.pcz.czest.pl
}

\begin{abstract}
Thermal methods of sludge disintegration can be divided into high temperature (over $100^{\circ} \mathrm{C}$ ) and low temperature (below this temperature). They consist in the supply or removal of thermal energy, contributing to the changes in sludge structure and physicochemical properties. During the chemical disintegration of excess sludge with sodium hydroxide, there is an increase in the $\mathrm{pH}$ value, as well as changes in their structure. The $\mathrm{OH}$ - ions are highly toxic to the microorganisms living in the excess sludge and affect the decline of biological activity of most microorganisms. The aim of the conducted research was to prove the impact of the thermal and alkaline disintegration of excess sludge on the susceptibility of organic substances to biodegradation. The thermal disintegration of excess sludge was carried out in a shaking water bath, in which the sludge placed in laboratory flasks with an active volume of $0.5 \mathrm{~L}$ were heated for a specified period within the scope of the so-called low temperatures, i.e. $65-95^{\circ} \mathrm{C}$. The sludge was heated for a period of $0.5-12 \mathrm{~h}$. The alkaline disintegration of the sludge was carried out with sodium hydroxide in the form of dust at ambient temperature, in sealed plastic bottles with an active volume of $5 \mathrm{~L}$, the contents of which were mixed manually every few hours. The regent doses in the range of $0.05-1.3 \mathrm{~g} \mathrm{NaOH} / \mathrm{g}$ VSS and disintegration time $12 \mathrm{~h}$ were used. As a result of subjecting the excess sludge to disintegration by means of the selected methods, an increase in the concentration of organic substances in the dissolved form in the supernatant liquid was noted. On the basis of the increase in SCOD, TOC value and VFAs concentration, the most favorable modification conditions were determined. As a result of disintegration of the sludge and subsequent methane fermentation, the supporting effects of the applied modification methods were observed, in relation to the conventional methane fermentation of excess sludge.
\end{abstract}

Keywords: excess sludge, thermal disintegration, alkaline disintegration, soluble chemical oxygen demand (SCOD), total organic carbon (TOC), volatile fatty acids (VFAs), methane fermentation

\section{INTRODUCTION}

Excess sludge formed as a result of wastewater treatment with the waste activated sludge method is directed to separate closed fermentation chambers during the technological process of the wastewater treatment plant. The excess sludge generated in the processes of highly effective methods of wastewater treatment contains about $97 \%$ water and $30 \%$ to $50 \%$ mineral substances. According to Stier and Fischer [Stier and Fischer, 1989.], the excess sludge is characterized by a significant content of organic matter at the level of $65-75 \%$ of dry matter. In addition, the excess sludge is characterized by limited biodegradability resulting from the large number of facultative bacteria present in it. Therefore, it is advisable to subject the excess sludge to disintegration, leading to a change in its structure. In addition, liquefaction of high-molecular compounds contained in the sludge is observed, which available for anaerobic microorganisms conducting the methane fermentation process [Erden and Filibeli, 2010; Kidak et al, 2009; Nanzai et al. 2009; Stier and Fischer, 1989; Zielewicz et al., 2008].

Disintegration of sewage sludge is a dynamically developing issue conditioning the effectiveness of the anaerobic stabilization process. It is 
a process involving the introduction of external energy into the sludge to destroy the structure of the sludge, as well as the cell membranes of microorganisms present in the sewage sludge. The destruction of the sludge structure by external forces affects the release of intracellular components that condition faster and more intense stabilization. The use of disintegration reduces the time of the anaerobic stabilization process, accelerates the hydrolysis process by transferring the organic charge from the solid phase of the sludge to the dissolved phase. The disintegration effect is the increase in the concentration of organic substances in dissolved form, expressed in the increase in the values of indicators such as: total organic carbon TOC, soluble chemical oxygen demand (SCOD), volatile fatty acids (VFAs) [Grübel, 2013; Wojtowicz, 2006].

Chemical disintegration is one of the effective methods of sludge disintegration. The chemical methods of disintegration, the essence of which is based on energy from chemical reactions, can be divided into the oxidation and neutralization processes. It involves the use of acid solutions, bases, detergents, antibiotics or organic solvents that effectively destroy the lipoproteins from the cell walls of microorganisms, lead to denaturation of proteins and, as a result, contribute to the deactivation of microorganisms living in excess sludge. An increase or decrease in $\mathrm{pH}$ causes a decrease or total loss of the biological activity of most microorganisms [Bednarski and Fiedurka, 2007; Marcinkowski, 2004.]. The $\mathrm{OH}-$ ions are highly toxic to the microorganisms living in the excess sludge and affect the decline of the biological activity of the microorganisms [Kim et al., 2003; Saktaywin et al., 2005; Stier and Fischer, 1989; Tak-Hyun Kim et al., 2009]. The hydroxides containing one hydroxyl group $(\mathrm{OH})$ cause a greater increase in the proportion of soluble chemical oxygen demand (SCOD) in total chemical oxygen demand (TCOD) than the hydroxides with two hydroxyl groups. Chemical modification is often used in combination with other methods to obtain the so-called hybrid processes [Wolny et al., 2008].

The thermal methods of sludge disintegration can be divided into high temperature (over $100^{\circ} \mathrm{C}$ ) and low temperature (below this temperature). They consist in the supply or removal of thermal energy to sludge, contributing to the changes in their structure and physicochemical properties [Iskra and Miodoński, 2014; Panter,
2014; Zawieja and Wolski, 2013]. This method consists in heating the excess sludge to a temperature at which the disintegration of microbial cells in the sludge, as well as the decomposition of biopolymers that form this sludge, occur. By subjecting the sludge to thermolysis, the microbial cell breaks down, and the amount of biological material present inside them is released. This increases the total organic carbon content in the aqueous phase to a great extent. The excess sludge liquefies due to the hydrolysis of complex organic compounds. Polysaccharides, lipids and proteins when heated in the presence of water form water-soluble mono- and oligomers, respectively [Podedworna and Umiejewska, 2008; Zheng et al., 1998]. According to Zawieja et al. [Zawieja et al., 2010], the effectiveness of thermal sludge modification depends on both the evaporation temperature and the disintegration time.

Submitting of the excess sludge to disintegration at temperatures over $200^{\circ} \mathrm{C}$ promotes the formation of refractive compounds that show low biodegradability [Stuckey and McCarty, 1984].

The aim of the conducted research was to prove the impact of the thermal and alkaline disintegration of excess sludge on the susceptibility of organic substances to biodegradation. The disintegration of sludge before the methane fermentation process plays an important role due to the fact that the transfer of nutrients from the activated sludge microorganisms to the anaerobic microorganisms responsible for the anaerobic stabilization process can only occur as a result of the hydrolysis process. As a result of disintegration, the lysing processes are initiated. In the anaerobic treatment of sludge, the hydrolysis process significantly determines the speed of the entire methane fermentation process.

\section{EXPERIMENTAL PART}

\section{Substrate of the research}

The excess sludge constituted the basic substrate of the research, which was taken from a mechanic-biological wastewater treatment plant. The wastewater treatment plant receives wastewater consisting in volume of $77 \%$ of municipal wastewater and $23 \%$ of industrial wastewater from a fiberboard production plant. The industrial wastewater contains, among others, dissolved and colloidal substances, i.e.: resins, waxes, tannins, 
dyes separated from wood and their breakdown products, carbohydrates (glucose, mannose, arabinose, xylose) and suspended, i.e. wood fiber. Therefore, the sludge from fiberboard production, according to the literature [Zhongtang and Mohn, 2001], show limited susceptibility to the methane fermentation process and it is advisable to disintegrate them.

The sludge samples were subjected to analysis and technological research on the day of collection. All indicators were determined using a three-point repetition. The excess sludge used for the research was sampled directly before mechanical thickening. Table 1 presents general characteristics of the researched sludge, including the values of selected indicators.

\section{Methodology of the research}

The thermal disintegration of the excess sludge was carried out in a shaking water bath, in which the sludge placed in laboratory flasks with an active volume of $0.5 \mathrm{~L}$ were heated for a specified period within the scope of the so-called low temperatures, i.e. $65-95^{\circ} \mathrm{C}$. The sludge was heated for a period of $0.5 \mathrm{~h}-12 \mathrm{~h}$.

The alkaline disintegration of the sludge was carried out with sodium hydroxide in the form of dust at ambient temperature, in sealed plastic bottles with an active volume of $5 \mathrm{~L}$, the contents of which were mixed every few hours. The regent doses in the range of $0.05-1.0 \mathrm{~g} \mathrm{NaOH} / \mathrm{g}$ VSS and disintegration time $12 \mathrm{~h}$ were used.

In the case of conducted research, the following indicators were determined:

Table 1. Selected physicochemical indicators of sludge

\begin{tabular}{|c|c|c|}
\hline \multirow{2}{*}{ Indicator/Unit } & \multicolumn{2}{|c|}{$\begin{array}{c}\text { The type of sludge used in the } \\
\text { research }\end{array}$} \\
\cline { 2 - 3 } & Excess sludge & $\begin{array}{c}\text { Digested sludge } \\
\text { (inoculum) }\end{array}$ \\
\hline $\mathrm{TS}, \mathrm{g} / \mathrm{L}$ & $15.8 \pm 0.5$ & $10.7 \pm 0.2$ \\
\hline $\mathrm{VSS}, \mathrm{g} / \mathrm{L}$ & $13.2 \pm 0.6$ & $6.4 \pm 0.8$ \\
\hline $\mathrm{SCOD}, \mathrm{mg} \mathrm{O} / \mathrm{L}$ & $1052 \pm 7$ & $1456 \pm 12$ \\
\hline $\begin{array}{c}\mathrm{VFAs}, \\
\mathrm{CH}_{3} \mathrm{COOH} / \mathrm{L}\end{array}$ & $238 \pm 2$ & $557 \pm 4$ \\
\hline $\mathrm{TOC}^{\mathrm{mg} \mathrm{CaCO}} / \mathrm{L}$ & $263 \pm 0.7$ & $465 \pm 0.3$ \\
\hline $\mathrm{pH}$ & $6.5 \pm 0.04$ & $7.2 \pm 0.02$ \\
\hline
\end{tabular}

TS - total solids,

VSS - volatile suspended solids,

SCOD - soluble chemical oxygen demand,

VFAs - volatile fatty acids,

TOC - total organic carbon.
- total solids (TS) and volatile suspended solids (VSS) according to PN-EN-12879,

- soluble chemical oxygen demand (SCOD) by the dichromate method using spectrophotometer tests by $\mathrm{HACH} 2 \mathrm{I} 00 \mathrm{~N}$ IS according to ISO 7027,

- volatile fatty acids (VFAs) according to PN-75/C-04616/04,

- the total organic carbon (TOC) value with spectrophotometric method in the infrared (carbon analyzer multi N/C manufactured by Analytik Jena),

- $\mathrm{pH}$ according to $\mathrm{PN}-91 / \mathrm{C}-04540 / 05$,

- as well as disintegration degree $\left(\mathrm{DD}_{\mathrm{SCOD}}\right)$ estimated in accordance with the equation given by Thiem and others [Müller, 1996].

The percentage increase in SCOD, i.e. $\mathrm{DD}_{\mathrm{SCOD}}$, was calculated according to the equation

$$
D D_{S C O D}=\frac{S C O D_{d}-S C O D_{0}}{S C O D_{a}-S C O D_{0}} \cdot 100 \%
$$

where: $D D_{S C O D}$-degree of sludge disintegration, $\%$; $S C O D_{d}$ - chemical oxygen demand determined in the filtrate after $0.45 \mu \mathrm{m}$ filter, for the sample after disintegration, $\mathrm{mg}$ $\mathrm{O}_{2} / \mathrm{L}$; $S C O D_{0}$ - chemical oxygen demand determined in the filtrate after $0.45 \mu \mathrm{m}$ filter, for the sample before disintegration, $\mathrm{mg}$ $\mathrm{O}_{2} / \mathrm{L}$; $\mathrm{SCOD}$ - chemical demand for oxygen determined in the filtrate after a chemical disintegration process with a $1-\mathrm{mol} \mathrm{NaOH}$ solution in a volume ratio of sediments to a $1: 1$ solution at $90^{\circ} \mathrm{C}$ for 10 minutes, $\mathrm{mg}$ $\mathrm{O}_{2} / \mathrm{L}$. The SCOD of the reference sample was equal to $3438 \mathrm{mg} \mathrm{O}_{2} / \mathrm{L}$

As a result of subjecting the excess sludge to disintegration by means of the selected methods, an increase in the concentration of organic substances in the dissolved form in the leachate was noted. On the basis of the increase in soluble chemical oxygen demand (SCOD), total organic carbon (TOC) value and volatile fatty acids (VFAs) concentration, the most favorable modification conditions were determined.

The following mixtures of sludge were subjected to methane fermentation:

- non-conditioned excess sludge + digested sludge (inoculum);

- chemically disintegrated excess sludge using sodium hydroxide with the dose $0.15 \mathrm{~g}$ 
$\mathrm{NaOH} / \mathrm{g}$ VSS and disintegration time $12 \mathrm{~h}+$ digested sludge (inoculum);

- thermally disintegrated excess sludge at $75^{\circ} \mathrm{C}$ for 6 hours + digested sludge (inoculum).

\section{RESULTS AND DISCUSSION}

\section{Determination of the conditions of alkaline disintegration of excess sludge}

As a result of subjecting the excess sludge to chemical disintegration, an increase in the concentration of organic substances in the dissolved form in the supernatant liquid was noted. On the basis of the increase in SCOD, TOC value and VFAs concentration, the most favorable modification conditions were determined. Moreover, the $\mathrm{pH}$ of the modified sludge was determined. Figure 1 shows the changes of the SCOD values determined in the leachate of excess sludge subjected to alkaline disintegration, while figure 2 presents the changes in the $\mathrm{pH}$ value of the sludge leachate undergoing chemical disintegration.

As a result of submitting the excess sludge with the alkaline disintegration at doses in the range from 0.05 to $1.3 \mathrm{~g} \mathrm{NaOH} / \mathrm{g}$ VSS, the SCOD values were obtained in the range from 1700 to $8768 \mathrm{mg} \mathrm{O}_{2} / \mathrm{L}$ (Figure 1). The SCOD value of the leachate increased along with the dose of the reagent increased. However, a similar SCOD value was obtained for doses of $0.7,1.0,1.15$ and $1.3 \mathrm{~g}$ $\mathrm{NaOH} / \mathrm{g}$ VSS.

The alkaline disintegration of excess sludge with sodium hydroxide, along with an increase in the dose of reagent, caused the $\mathrm{pH}$ of the supernatant to increase. In the range of used sodium hydroxide (from 0.05 to $13 \mathrm{~g} \mathrm{NaOH} / \mathrm{g}$ VSS during $12 \mathrm{~h}$ ) the $\mathrm{pH}$ of the leachate increased from 6.8 (sample 0) to 12.8. For technological reasons, the dose $0.15 \mathrm{~g} \mathrm{NaOH} / \mathrm{g}$ VSS was considered optimal, recording the $\mathrm{pH}$ value of 7.4 . Figure 3 presents

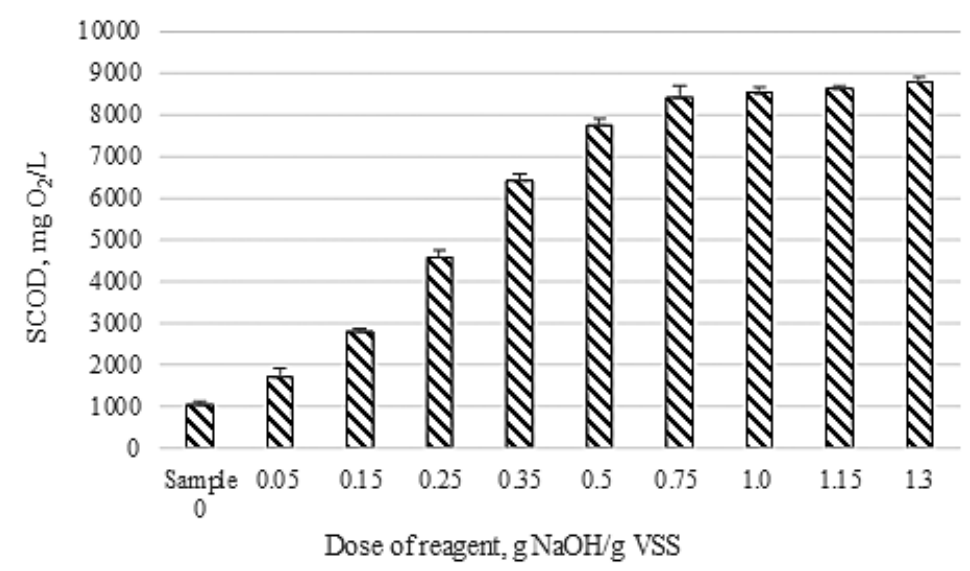

Fig. 1. Changes of SCOD values determined in the leachate of excess sludge subjected to alkaline disintegration by the period of $12 \mathrm{~h}$

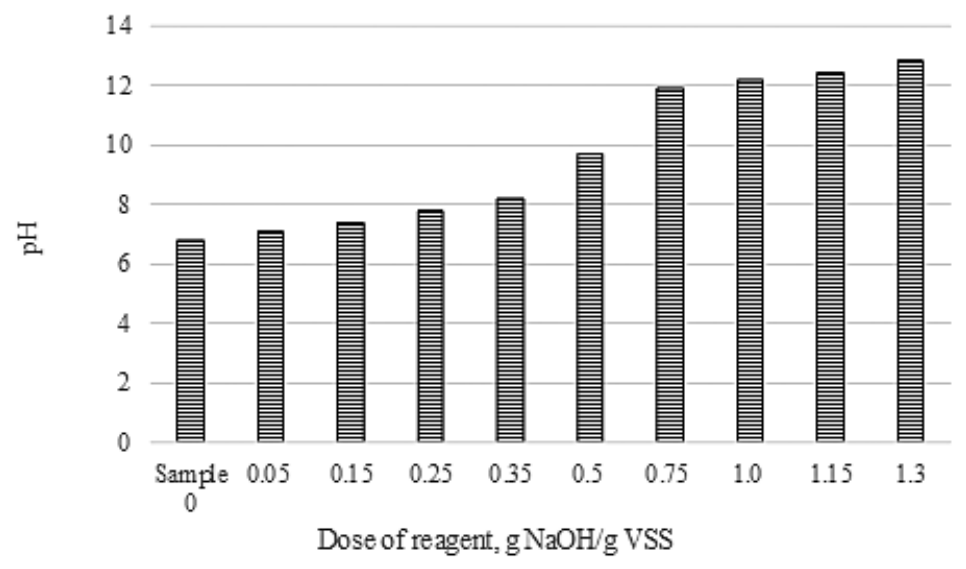

Fig. 2. Changes of the $\mathrm{pH}$ values determined in the leachate of excess sludge subjected to alkaline disintegration for the period of $12 \mathrm{~h}$ 


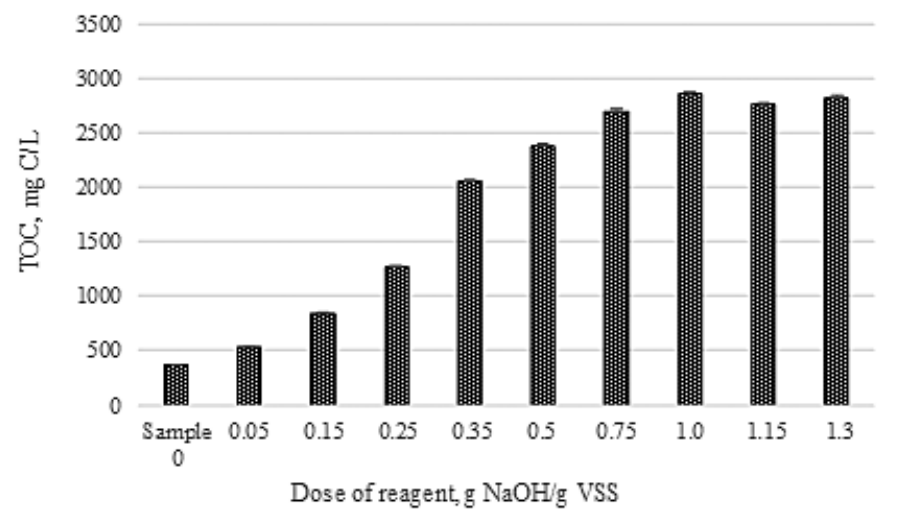

Fig. 3. Changes of the TOC values determined in the leachate of excess sludge subjected to the alkaline disintegration by the period of $12 \mathrm{~h}$

the changes in the TOC value of the sludge undergoing alkaline disintegration.

It was noted that the changes of the TOC values recorded in the leachate of the alkaline disintegrated excess sludge, correlate with the changes in the SCOD value. The changes of the volatile fatty acids concentration in the excess sludge leachate in the process of alkaline disintegration are shown in Figure 4.

The highest value of VFAs concentration i.e. $1691 \mathrm{mg} \mathrm{CH} \mathrm{COOH}_{3} \mathrm{~L}$ was noticed for the dose of $1.3 \mathrm{~g} \mathrm{NaOH} / \mathrm{g}$ VSS of sludge. With the increase of the reagent dose, the increase of the volatile fatty acids concentration of was observed. In addition, for the dose of $0.15 \mathrm{~g} \mathrm{NaOH} / \mathrm{g} \mathrm{VSS}$, the concentration of VFAs was equal to $428 \mathrm{mg}$ $\mathrm{CH}_{3} \mathrm{COOH} / \mathrm{L}$. This dose of reagent was considered, due to the methane fermentation process conditions, especially $\mathrm{pH}$ value, the most favorite. Figure 5 presents the changes of the disintegration degree (DD) values of the sludge undergoing the alkaline disintegration.
As a result of subjecting the excess sludge to the alkaline disintegration for the tested reagent doses, the disintegration degree of sludge was obtained in the range from 7.9 to $91.6 \%$. According to Rajan et al. [Rajan et al., 1989] as a result of excess sludge subjecting to the alkaline disintegration with sodium hydroxide, about $46 \%$ disintegration degree was obtained, while Penaund et al. [Penaund et al., 1999] achieved a disintegration degree of approximately $65 \%$.

\section{Determination of the conditions of alkaline disintegration of excess sludge}

As a result of initiating the thermolysis process of organic substances contained in modified excess sludge, an increase in the concentration of organic matter in dissolved form was noted. A proportional increase in the value of tested physicochemical indicators was observed along with the increase of temperature and preparation time. Figure 6 shows the changes of SCOD values determined in the leachate of excess sludge

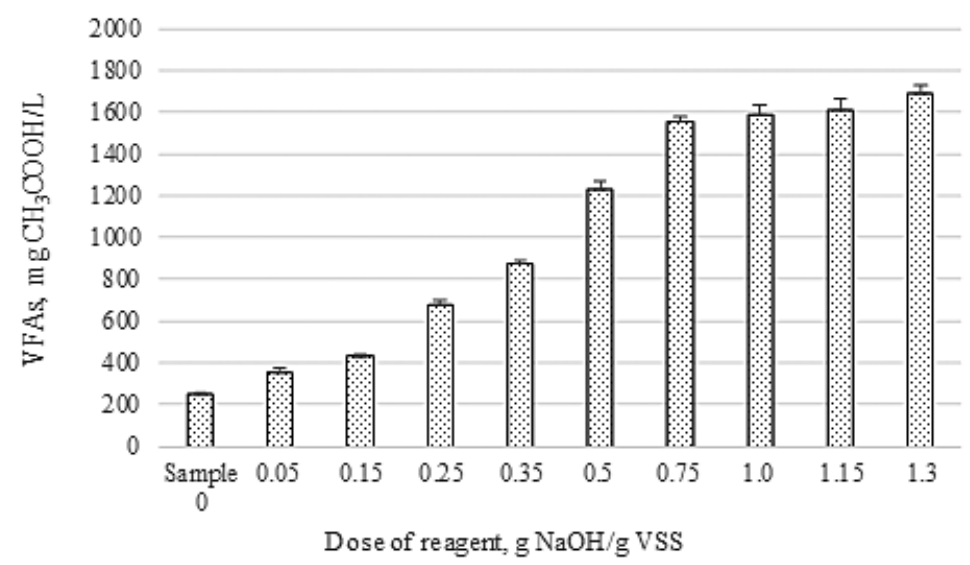

Fig. 4. Changes of VFAs concentration determined in the leachate of excess sludge subjected to the alkaline disintegration for the period of $12 \mathrm{~h}$ 


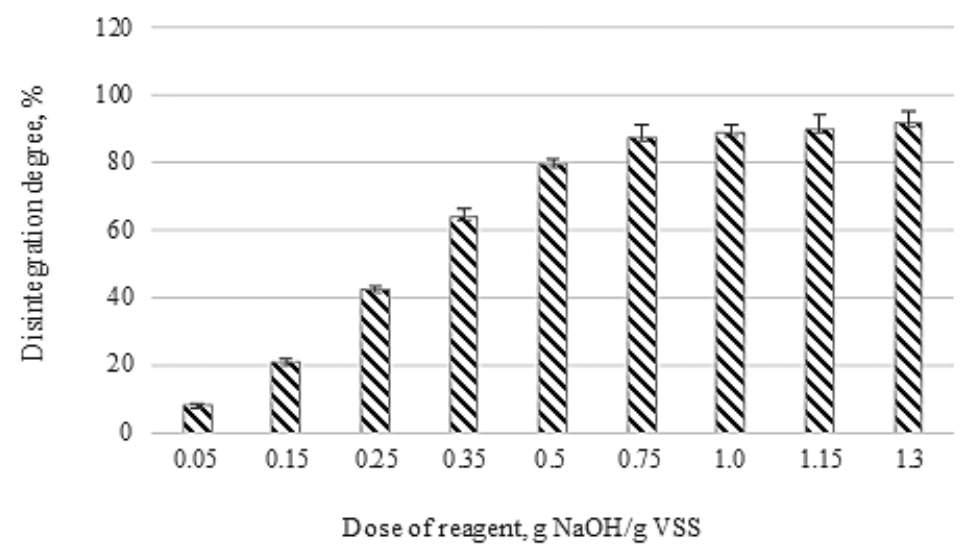

Fig. 5. Disintegration degree of the excess sludge submitted to the alkaline modification

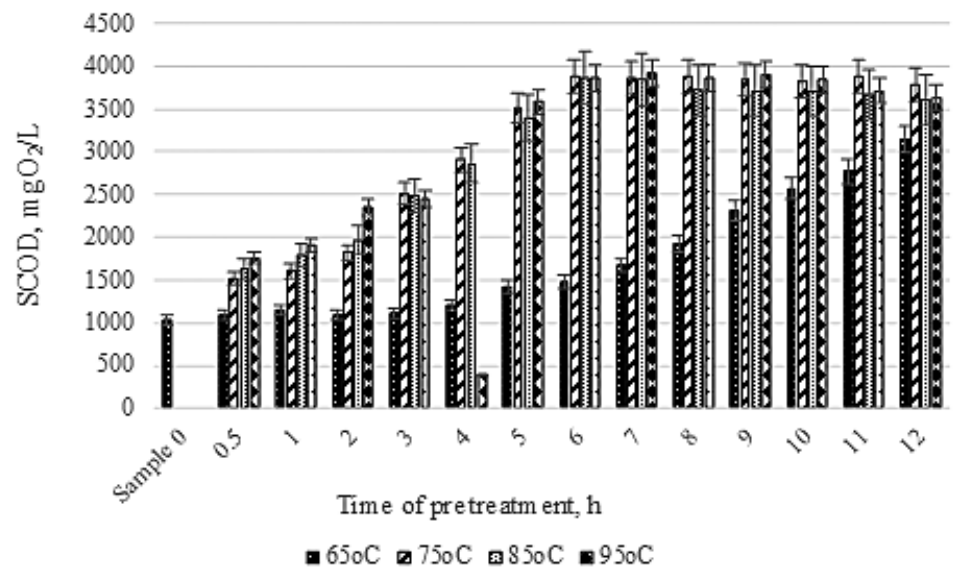

Fig. 6. Changes of the SCOD values determined in the leachate of the excess sludge subjected to thermal disintegration

subjected to thermal disintegration, while Table 2 presents the most favorable conditions for thermal modification of excess sludge.

The data presented in Figure 8 show that the soluble chemical oxygen demand (SCOD) values of the modified excess sludge increased along with the temperature and modification tim,. In the case of thermal modification at $70^{\circ} \mathrm{C}$, in relation to the tested values of temperature, for the time of $6 \mathrm{~h}$ the optimum increase of SCOD equal $3876 \mathrm{mgO}_{2} / \mathrm{L}$ was noticed. In addition, in relation to the initial value of SCOD, determined for the non-modified sludge, a 4-fold increase in the value of the mentioned indicator was obtained for the above-mentioned disintegration conditions. Myszograj et al. [Myszograj et al., 2013] received for the modification time of excess sludge $2 \mathrm{~h}$ and preparation temperature of $175^{\circ} \mathrm{C}$, about $54 \%$ increase in SCOD value, while Borges and Chernicharo [Borges and Chernicharo, 2009] for $75^{\circ} \mathrm{C}$ temperature and $7 \mathrm{~h}$ time about $35 \%$ increase in SCOD value. The changes of total organic carbon values in time for different values of temperature are presented in Figure 7. Table 3 shows, the most favorable conditions for the thermal disintegrated excess sludge evaluated on the basis of the increase in the TOC value.

It was noted that the changes of the TOC values observed in the leachate of the thermal disintegrated excess sludge, correlate with the changes in the SCOD values. In relation to the initial value of TOC, determined for non-modified sludge, a 4-fold increase of the value of the tested indicator was obtained for the temperature of $70^{\circ} \mathrm{C}$ and the time of pretreatment of $6 \mathrm{~h}$. The changes of the volatile fatty acids concentration in leachate of alkaline disintegration excess sludge are shown in Fig. 8. Table 4 shows the most favorable conditions for the thermal disintegrated excess sludge evaluated on the basis of the increase in the VFAs concentration.

It was observed that the VFAS concentration in the leachate gradually increased along with the temperature of preparation and 
Table 2. Most favorable conditions for the thermal modification of the excess sludge, based on the increase in the SCOD value

\begin{tabular}{|c|c|c|c|c|}
\hline Temperature, ${ }^{\circ} \mathrm{C}$ & $\begin{array}{c}\text { The most favourable } \\
\text { exposure time, } \mathrm{h}\end{array}$ & $\begin{array}{l}\mathrm{SCOD}{ }_{\text {non-modified excess sludge, }} \\
\mathrm{mgO} \mathrm{O}_{2} / \mathrm{L}\end{array}$ & $\begin{array}{l}\mathrm{SCOD} \\
\text { thermally modified excess } \\
\text { sludge, } \mathrm{mgO}_{2} / \mathrm{L}\end{array}$ & $\begin{array}{l}\text { Ratio of SCOD } \text { thermally modified }_{\text {ex }} / \mathrm{SCOD}_{\text {non-modified }} \\
\text { excess sludge }\end{array}$ \\
\hline 65 & 12 & 1033 & 3151 & $1 / 3$ \\
\hline 75 & 6 & 1033 & 3876 & $1 / 4$ \\
\hline 85 & 6 & 1033 & 3861 & $1 / 4$ \\
\hline 95 & 7 & 1033 & 3912 & $1 / 4$ \\
\hline
\end{tabular}

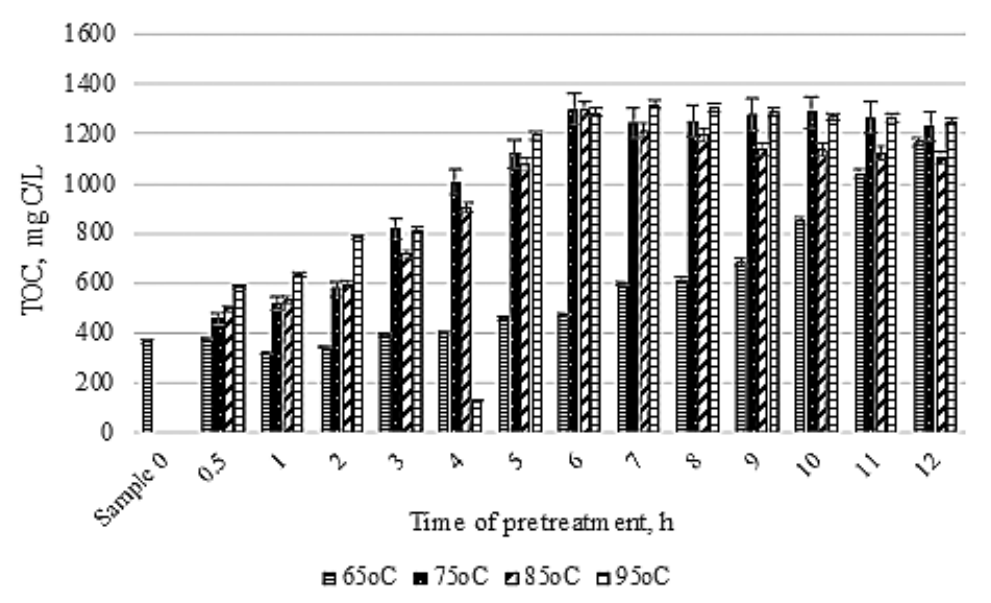

Fig. 7. Changes of the TOC values determined in the leachate of excess sludge subjected to thermal disintegration

modification time. The concentration of VFAs of $775 \mathrm{mg} \mathrm{CH} \mathrm{COOH}_{3} \mathrm{~L}$ was noticed for the temperature of $75^{\circ} \mathrm{C}$ and the time of $6 \mathrm{~h}$, a 3-fold increase of the VFAs concentration occurred compared to the VFAs of the non-prepared excess sludge. Moreover, the increase of VFAs concentration correlated with the increase of the SCOD and TOC values in the leachate of the modified sludge. Figure 9 presents the changes of the disintegration degree $\left(\mathrm{DD}_{\mathrm{SCOD}}\right)$ values of the sludge undergoing thermal disintegration.

As a result of subjecting the excess sludge to thermal disintegration for the tested values of the temperature, the disintegration degree of sludge was obtained in the range from 0.7 to $34.1 \%$. For a modification temperature of $75^{\circ} \mathrm{C}$ and a preparation time of $6 \mathrm{~h}$, the disintegration degree was $33.7 \%$. It was noted that for higher temperature values, i.e. 75,86 and $95^{\circ} \mathrm{C}$, and modification time in the range from 6 to 12 hours, a similar value of disintegration degree was obtained. Karczmarek and Gaca [Karczmarek and Gaca, 2015] obtained the disintegration degree in the range of 51 to $66 \%$ for a temperature in the range of $160-170^{\circ} \mathrm{C}$ and pressure of 6 bar. On the other hand, Zawieja et al. [Zawieja and Wolski, 2013] obtained a 75\% disintegration degree for a temperature of $90^{\circ} \mathrm{C}$ and modification time of 3 hours.

\section{Conventional methane fermentation and aided disintegration process}

In order to increase the susceptibility to biodegradation, the excess sludge was subjected to a disintegration process. The excess sludge generated in the effect of advanced

Table 3. Determination of the most favorable conditions for the thermal modification of the excess sludge on the basis of the increase in the TOC value

\begin{tabular}{|c|c|c|c|c|}
\hline Temperature, ${ }^{\circ} \mathrm{C}$ & $\begin{array}{c}\text { The most favourable } \\
\text { exposure time, } \mathrm{h}\end{array}$ & $\begin{array}{c}\text { TOC non-modified excess sludge' } \\
\mathrm{mgO}_{2} / \mathrm{L}\end{array}$ & $\begin{array}{l}\text { TOC } \text { thermally modified excess } \\
\text { sludge, } \mathrm{mgO}_{2} / \mathrm{L}\end{array}$ & $\begin{array}{l}\text { Ratio of } \mathrm{TOC}_{\text {thermally modified }} \\
\text { excess sludge } \\
\text { excess sludae }\end{array}$ \\
\hline 65 & 12 & 365 & 1169 & $1 / 3$ \\
\hline 75 & 6 & 365 & 1299 & $1 / 4$ \\
\hline 85 & 6 & 365 & 1298 & $1 / 4$ \\
\hline 95 & 7 & 365 & 1318 & $1 / 4$ \\
\hline
\end{tabular}




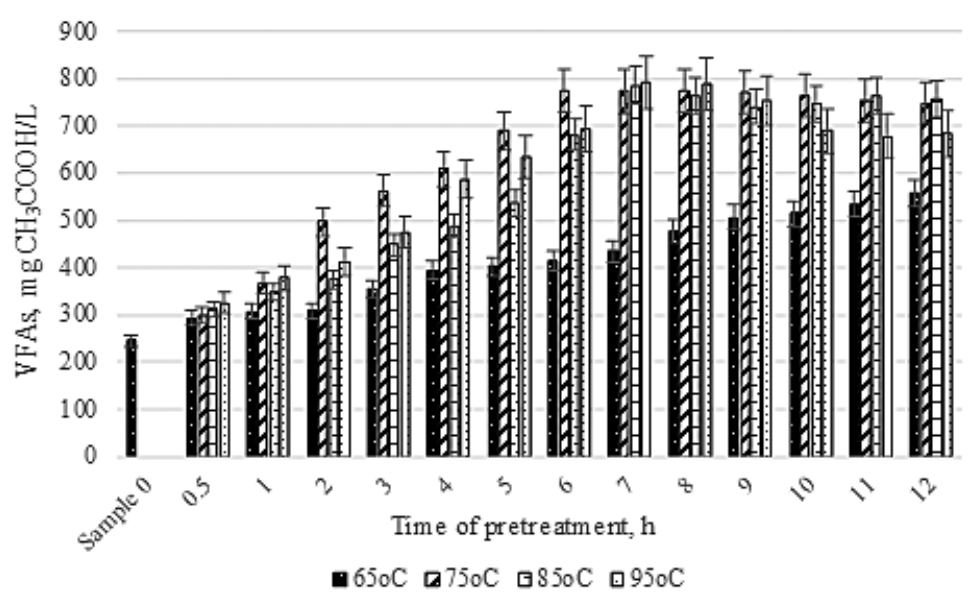

Fig. 8. Changes of the VFAs concentration determined in the leachate of excess sludge subjected to thermal disintegration

Table 4. Determination of the most favorable conditions for the thermal modification of the excess sludge on the basis of the increase in the VFAs concentration

\begin{tabular}{|c|c|c|c|c|}
\hline Temperature, ${ }^{\circ} \mathrm{C}$ & $\begin{array}{c}\text { The most favourable } \\
\text { exposure time, } \mathrm{h}\end{array}$ & $\begin{array}{l}\text { VFAs } \\
\text { sludge, } \\
\text { ng CH-modified excess } \\
\end{array}$ & $\begin{array}{l}\text { VFAs } \\
\text { sludge } \\
\text { shermally modified excess } \\
\text { lin }\end{array}$ & $\begin{array}{c}\text { Ratio of VFAs } \\
\text { modermally } \\
\text { modified excess sludge } \\
\text { non-modified excess sludae }\end{array}$ \\
\hline 65 & 12 & 246 & 559 & $1 / 2$ \\
\hline 75 & 6 & 246 & 775 & $1 / 3$ \\
\hline 85 & 7 & 246 & 786 & $1 / 3$ \\
\hline 95 & 7 & 246 & 792 & $1 / 3$ \\
\hline
\end{tabular}

wastewater treatment by means of the activated sludge method shows low biodegradability. As a result of subjecting the alkaline, as well as the thermal disintegrated excess sludge to methane fermentation, increases in the soluble chemical oxygen demand (SCOD) and total organic carbon (TOC) values were noted in subsequent days of the methane fermentation process. The observed increase in the digestion degree of sludge confirmed the supporting effect of both the alkaline and thermal modification methods of excess sludge. As a result of combining the disintegration process with the methane fermentation process, the concentration of organic substances in the dissolved form was increased in relation to conventional methane fermentation. The intensification of the hydrolytic phase of the process was observed. Table 5 shows the values of the digestion degree of sludge and the maximum values of indicators, such as SCOD, VFAs and TOC determining the course of the methane fermentation process.

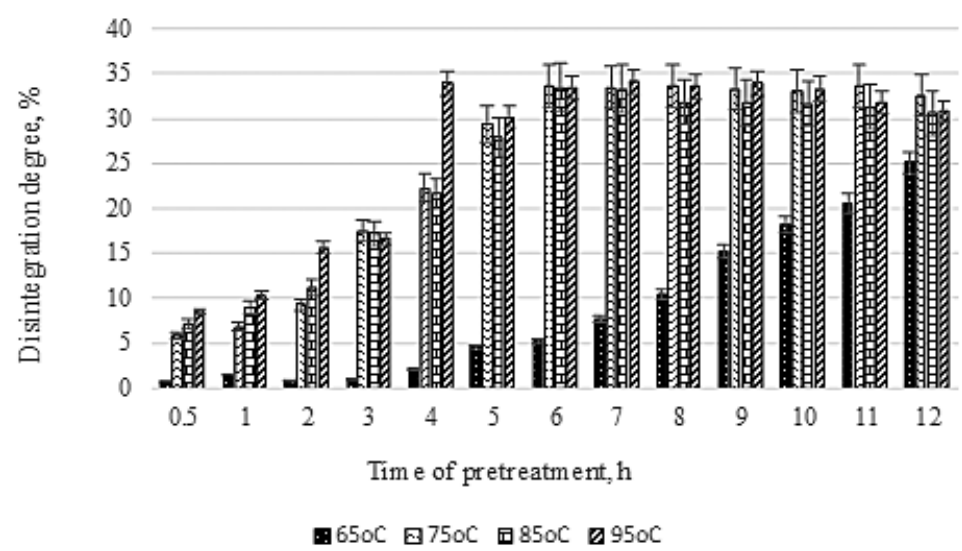

Fig. 9. Disintegration degree of excess sludge submitted thermal modification 
Table 5. Digestion degree of sludge and maximum COD, TOC and VFAs concentrations obtained in the process of 10-day methane fermentation of the non-modified and disintegrated sludge with the selected methods

\begin{tabular}{|c|c|c|c|}
\hline \multirow{3}{*}{$\begin{array}{r}\begin{array}{r}\text { The methane } \\
\text { fermentation } \\
\text { conditions }\end{array} \\
\text { Indicator }\end{array}$} & \multirow{3}{*}{$\begin{array}{l}\text { Conventional methane } \\
\text { fermentation }\end{array}$} & \multicolumn{2}{|c|}{$\begin{array}{l}\text { Methane fermentation of excess sludge subjected to disintegration with } \\
\text { the use of the most favorable modification conditions }\end{array}$} \\
\hline & & Alkaline disintegration & Thermal disintegration \\
\hline & & $0.15 \mathrm{~g} \mathrm{NaOH} / \mathrm{g}$ VSS, $\mathrm{t}=12 \mathrm{~h}$ & $\mathrm{~T}=75^{\circ} \mathrm{C}, \mathrm{t}=6 \mathrm{~h}$ \\
\hline Digested degree, $\%$ & 19 & 27 & 30 \\
\hline $\begin{array}{l}\text { Maximum value of } \\
\mathrm{SCOD}, \mathrm{mg} \mathrm{O}_{2} / \mathrm{L}\end{array}$ & $\begin{array}{c}1145 \\
\text { (6th day) }\end{array}$ & 2976 (3th day) & 4312 (4th day) \\
\hline $\begin{array}{l}\text { Maximum value of } \\
\text { TOC, } \mathrm{mg} \mathrm{C/L}\end{array}$ & $\begin{array}{c}438 \\
\text { (6th day) }\end{array}$ & 856 (3th day) & 1834 (4th day) \\
\hline $\begin{array}{l}\text { Maximum value of } \\
\text { VFAs, } \mathrm{mgCH}_{3} \mathrm{COOH} / \mathrm{L}\end{array}$ & $\begin{array}{c}531 \\
\text { (6th day) }\end{array}$ & 1483 (3th day) & 1431 (4th day) \\
\hline
\end{tabular}

In the methane fermentation process of the alkaline disintegrated sludge with the dose $0.15 \mathrm{~g} \mathrm{NaOH} / \mathrm{g} \mathrm{VSS}$, the highest values of the analyzed indicators, i.e. SCOD, TOC and VFAs concentration, were obtained on the 3th day of the process. A $27 \%$ digestion degree of sludge was noticed. In the case of methane fermentation of the thermally disintegrated excess sludge at temperature of $70^{\circ} \mathrm{C}$, the highest values of the mentioned indicators were obtained on the 4th day of the process. A $30 \%$ digestion degree of sludge was obtained. For methane fermentation of the excess sludge disintegrated at 60 and $80^{\circ} \mathrm{C}$ (preparation time 1h), Riyadh et al. [Riyadh et al., 2012] obtained about 7 and $17 \%$ increase in the digestion degree of sludge, in relation to methane fermentation of untreated sludge.

Figure 10 presents the values of the VFAs/Alkalinity ratio noticed during the process of methane fermentation.

In the following days of the methane fermentation process of the untreated sludge, as well as the sludge subjected to disintegration, a gradual decrease in the VFAs/Alkalinity ratio was noted, which indicates the correctness of the stabilization process.

\section{CONCLUSIONS}

The disintegration is a promising technology to improve the biodegradability of the excess sludge. In order to increase the concentration of organic matter of the excess sludge in the dissolved form, the excess sludge was subjected to the alkaline and thermal modification. It should be emphasized that the excess sludge arising in the processes of advanced wastewater treatment with the activated sludge method shows limited susceptibility to the methane fermentation process. As a result of subjecting the excess sludge to the selected disintegration method, an increase in the value of SCOD and TOC as well as an intensification of VFAs generation was noted. In the case of methane fermentation of the modified sludge, in relation to conventional methane

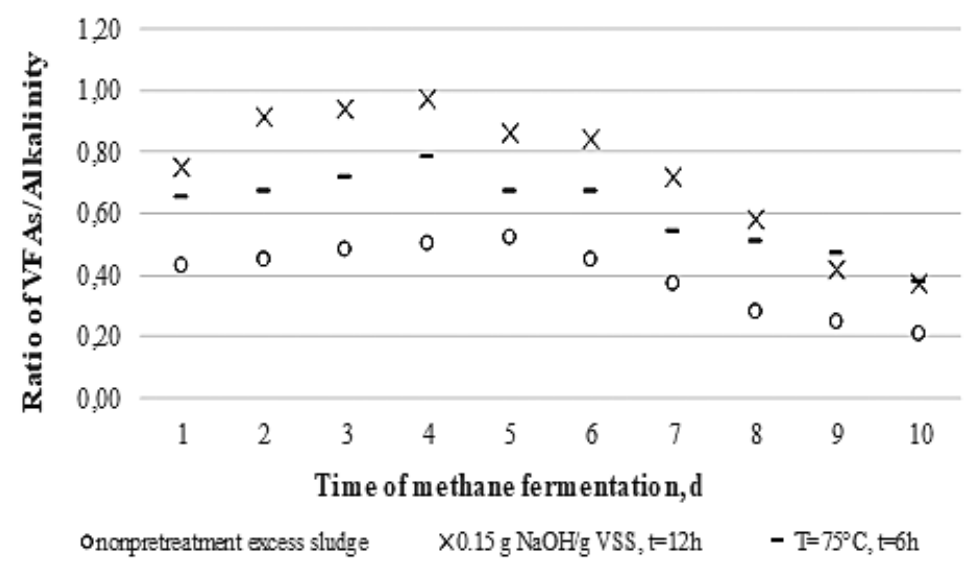

Figure 10. Changes of the VFAs/Alkalinity ratio in the process of conventional methane fermentation of the excess sludge and methane fermentation of the sludge disintegrated by means of the thermal and alkaline methods 
fermentation, the supporting effect of the chemical and physical methods on the process was observed. An increase in the digestion degree as well as the values of the tested physicochemical indicators was obtained. As a result, the following conclusions were drawn:

1. In the case of the alkaline disintegration for the selected doses of the reactant, an increase in liquefaction of excess sludge was observed compared to the non-conditioned sludge. The dose of $0.15 \mathrm{~g} \mathrm{NaOH} / \mathrm{g}$ VSS was recognized as the most beneficial for technological reasons of the methane fermentation process. For the tested reagent dose, a $\mathrm{pH}$ value of 7.4 was obtained.

2. The thermal modification of the excess sludge led to the increase of the concentrations of organic substances in dissolved form with respect to the values obtained for the non-conditioned sludge. In the case of the thermal disintegration at $70^{\circ} \mathrm{C}$, in relation to the tested values of temperature, for the preparing time of $6 \mathrm{~h}$ the highest increases of SCOD, DDSCOD, TOC and VFAs concentrations were obtained.

3 . In the 10-day conventional methane fermentation process, about $19 \%$ digestion degree was obtained, while in the case of the alkaline and thermal disintegrated excess sludge, about 27 and $30 \%$, respectively. The highest value of indicators such as SCOD, TOC and VFAs obtained on the 3th and 4th day of the process, indicate the intensification of the course of the hydrolysis phase.

\section{Acknowledgements}

The research was funded by the project No. BS/PB-400-301/19.

\section{REFERENCES}

1. Bednarski W., Fiedurka J. 2007. Basics of industrial biotechnology. Scientific and Technical Publishing House, Warsaw.

2. Borges E. S. M., Chernicharo C. A. L. 2009. Effect of thermal treatment of anaerobic sludge on the bioavailability and biodegradability characteristics of the organic fraction. Braz. J. Chem. Eng., 26(3), $469-480$.

3. Erden G., Filibeli A. 2010. Ultrasonic pre-treatment of biological sludge: consequences for disintegration, anaerobic biodegradability and filterability. Journal of Chemical Technology and Biotechnology, 85(1), 145-150.
4. Grübel K., Machnicka A., Nowicka E., Wacławek S. 2013. Mesophilic - thermophyte fermentation of disintegrated sludge in a hybrid process. Proceedings of ECOpole, 7(2), 567 - 573.

5. Iskra K., Miodoński S. 2014. Disintegration of excess sludge - good practice or necessity?. www. eko-dok.pl, Wroclaw University of Technology Publisher, 2014, 30.04.2018.

6. Karczmarek A. M., Gaca J. 2015. Effect of twostage thermal disintegration on particle size distribution in sewage sludge. Polish Journal of Chemical Technology, 3, 69 -73.

7. Kidak R., Wilhelm A.M., Delmas H.. 2009. Effect of process parameters on the energy requirement in ultrasonical treatment of waste sludge. Chemical Engineering and Processing, 2009, 48, 1346-1352.

8. Kim J., Park C., Kim T.H., Lee M., Kim S., Kim S.W., Lee J. 2003. Effects of various pretreatments for enhanced anaerobic digestion with waste activated sludge. J. Biosci. Bioeng., 95, 271-275.

9. Marcinkowski T. 2004. Alkaline stabilization of municipal sewage sludge. Scientific Works of the Institute of Engineering and Environmental Protection of the Wroclaw University of Technology, Publishing House of the Wroclaw University of Technology, Poland, Wroclaw.

10. Müller J. Mechanischer Kläschammaufschluss, Dissertation, TU Braunschweig, Shaker-Verlag, Aachen 1996.

11. Myszograj S., Jędrczak A., Suchowska-Kisielewicz M., Sadecka Z. 2013. Thermal and chemical disintegration of excessive sewage sludge. $1 \mathrm{st}$ Global Virtual Conference, http://www.gv-conference.com

12. Nanzai B., Okitsu K., Takenaka N., Bandow H., Tajima N., Maeda Y. 2009. Effect of reaction vessel diameter on sonochemical efficiency and cavitation dynamics, Ultrasonics Sonochemistry, 16, 163-168.

13. Penaund V., Delgenès J. P., Moletta R. 1999. Thermo-chemical pretreatment of microbial biomass: influence of sodium hydroxide addition on solubilization and anaerobic biodegradability. Enzyme Microb. Technol., 25, 1999, 258-263.

14. Panter K. 2014. Cambi thermal hydrolysis - getting the bugs out of digestion and dewatering. Proceedings of 3rd European Biosolids and Organic Residuals, Conference Wakefield, England,

15. http://www.cambi.no/photoalbum/view2/P3NpemU9b3JnJmlkPTIyMDA1NSZ0eXBIPTE.,

16. Podedworna J., Umiejewska K. 2008. Sewage sludge technology. Warsaw University of Technology Publishing House, Poland, Warsaw. 
17. Rajan R. V., Lin J. G., Ray B. T. 1989. Low-level chemical pretreatment for enhanced sludge solubilization. J. Wat. Pollut. Control Fed., 11/12, 1678-1683.

18. Riyadh S. Almukhtar, Asawer A. Alwasiti, Mohammed T. Naser. 2012. Enhancement of Biogas production and organic reduction of sludge by different pretreatment processes, Iraqi Journal of Chemical and Petroleum Engineering,13(1), 19-31.

19. Saktaywin W., Tsuno H., Nagare H., Soyama T., Weerapakkaroon J. 2005. Advanced sewage treatment process with excess sludge reduction and phosphorus recovery. Water Res., 39, 902-910.

20. Salyers A. A., Whitt D. D. 2012. Microbiology. PWN Scientific Publishing House, Warsaw.

21. Stier E., Fischer M. 1989. Handbook for operation of sewage treatment plants. Seidel-Przywecki Publishing House, Gliwice.

22. Stuckey D. C., McCarty P. L. 1984. The effect of thermal pre-treatment on the anaerobic biodegradability and toxicity of waste activated sludge, Water Res., 18, 1343-1353.

23. Tak-Hyun Kim, Sang-Ryul Lee, Youn-Ku Nam, Jeongmok Yang, Chulhwan Parkc, Myunjoo Lee. 2009. Disintegration of excess activated sludge by hydrogen peroxide oxidation. Desalination, 246, 275-284.

24. Wojtowicz A. 2006. Disintegration - introduction to the issue. Forum Explorer 1/(22), 34-38.
25. Wolny L., Zawieja I., Wolski P., Tomska A.. 2008. Combined methods of conditioning sewage sludge in the aspect of changing their structure, Energetic aspects of sewage disposal and treatment - I. Collective work edited by Łucja Fukas-Płonka and Karol Kuś, 239-250.

26. Zawieja I. Wolski P. 2013. Effect of hybrid method of excess sludge disintegration on the increase of their biodegradalibity. Environment Protection Engineering, 39(2), 153-165.

27. Zawieja I., Barański M., Małkowski M. 2010. Biogas generation during the anaerobic stabilization of thermally modified sewage sludge,. Engineering and Environmental Protection, 13(3), 2010, 185-196.

28. Zawieja I., Wolski P. 2013. Impact of chemical-thermal modification of excess sludge on the generation of volatile fatty acids in the methane fermentation process. Annual Set of Environmental Study, 15(3), 2054-2070.

29. Zheng J., Graff R.A., Fillos J., Rinard I. 1998. Incorporation of rapid thermal conditioning into a wastewater treatment plant. Fuel Processing Technology, 56, 183-200. 19

30. Zhongtang Yu., Mohn W.W. 2001. Bioaugmentation with resin acid degrading bacteria enhances resin acid removal in sequencing batch reactors treating pulp mill effluents. Wat. Res. 35 (4), 883-890.

31. Zielewicz E., Sorys P., Janik M., Fukas - Płonka Ł. 2008. Hybrid disintegration as a method of improving the effects of sludge stabilization. Engineering and Environmental Protection, 11(3), 397-409. 